\title{
René Corona, Diachronie, poésie et traduction. D'une langue à l'autre: la poésie, pourquoi?
}

\section{Fabio Scotto}

\section{Q OpenEdition}

1 Journals

\section{Edizione digitale}

URL: http://journals.openedition.org/studifrancesi/5774

DOI: ERREUR PDO dans /localdata/www-bin/Core/Core/Db/Db.class.php L.34 : SQLSTATE[HY000]

[2006] MySQL server has gone away

ISSN: 2421-5856

\section{Editore}

Rosenberg \& Sellier

\section{Edizione cartacea}

Data di pubblicazione: 1 septembre 2011

Paginazione: 459

ISSN: 0039-2944

\section{Notizia bibliografica digitale}

Fabio Scotto, «René Corona, Diachronie, poésie et traduction. D'une langue à l'autre: la poésie, pourquoi?», Studi Francesi [Online], 164 (LV | II) | 2011, online dal 30 novembre 2015, consultato il 07 janvier 2021. URL: http://journals.openedition.org/studifrancesi/5774 ; DOI: https://doi.org/ERREUR PDO dans / localdata/www-bin/Core/Core/Db/Db.class.php L.34 : SQLSTATE[HY000] [2006] MySQL server has gone away

Questo documento è stato generato automaticamente il 7 janvier 2021.

\section{(c)}

Studi Francesi è distribuita con Licenza Creative Commons Attribuzione - Non commerciale - Non opere derivate 4.0 Internazionale. 


\title{
René Corona, Diachronie, poésie et traduction. D'une langue à l'autre: la poésie, pourquoi?
}

\author{
Fabio Scotto
}

\section{NOTIZIA}

RENÉ CORONA, Diachronie, poésie et traduction. D'une langue à l'autre: la poésie, pourquoi?, Torino-Paris, L'Harmattan Italia, 2009, 157 pp.

1 Questo snello saggio di René Corona, ricercatore a Messina, poeta, scrittore e traduttore della poesia di Gesualdo Bufalino in francese (Le Miel amer, Coaraze, Éditions L'Amourier, 2006) ha il pregio di essere un utile strumento divulgativo che consente una riflessione documentata e storica sullo statuto della poesia e sulla sua evoluzione in Francia e in Italia, con riferimento alla teoria e alla prassi della traduzione, come attestano anche le sue prove d'autore autocommentate di liriche francesi barocche da Théophile de Viau, Jean de Sponde, François Mainard, Jean-Baptiste Chassignet, François de Malherbe e altri qui comprese. Articolato in otto capitoli, tra i quali si segnala in particolare il terzo, Les Deux Pays poétiques (pp. 28-39), che contiene anche utili carte sinottiche comparate sull'evoluzione della poesia nei due Paesi tra Otto e Novecento, il volume ha un taglio prevalentemente pedagogico, ma anche il pregio di filtrare criticamente numerose letture poetologiche aggiornate, cosicché il lettore è costantemente guidato in un'indagine che abbina elementi di storia della lingua e d'estetica del tradurre a uno sguardo comparatistico di taglio sociologico e sociolinguistico nel quale dominante è la poesia novecentesca. Ed è per l'appunto la prospettiva diacronica cui allude il titolo che con approcci stilistico-grammaticali e retorici trasforma il «pourquoi» della poesia in «comment» (p. 40), ovvero nell'ineludibilità del problema della forma. 
2 Dello stesso autore si segnala anche la più recente monografia Paul de Roux entre éblouissement et enchantement. La langue du poème (Torino-Paris, L'Harmattan Italia, 2010, 163 pp.), anch'essa improntata ad un'analisi di taglio linguistico-stilistico e traduttivo del corpus poetico del valente ma ancora poco noto poeta francese contemporaneo nato a Nîmes nel 1937. 